\title{
Robert D. Tollison: Father of sportometrics, friend and colleague
}

\author{
Raymond D. Sauer ${ }^{1}$
}

Received: 18 January 2017/Accepted: 31 January 2017/Published online: 14 February 2017

(C) Springer Science+Business Media New York 2017

\section{My friend and colleague at Clemson}

I met Bob Tollison for the first time at the 1989 meetings of the Southern Economic Association in Orlando, Florida. I will always remember the moment. I was a young assistant professor at the time, and had read several of Bob's papers in graduate school. Tollison was the Duncan Black Professor of Economics and Director of the Center for Study of Public Choice at George Mason University. It was a great night for me, as I had never been in the company of so many outstanding economists. As I was introduced to Tollison, he told me in his soft but steady voice, "It's nice to meet you. I read your recent paper in the JPE (Sauer 1988). It's a very good paper." Cigars were lit and liquor flowed that night, but I was already on cloud nine.

Thirteen years later he became my colleague in the Department of Economics at Clemson. Not long thereafter I was appointed as his "boss-man." "Hey boss-man!" was his standard way of greeting me, even after I stepped down as department chair last year. He had kind words for me then, too, expressing a sincere appreciation that made the hassle of being chair worthwhile. Bob himself was no hassle at all. Affable and knowledgeable, kind but witty, it is hard to imagine a better colleague.

Tollison was the ultimate WYSIWYG chaired professor, the J. Wilson Newman Professor of Managerial Economics in his last years at Clemson. A man of routine, he arrived early for work each day before classes began. His door was always open and his desk often was clear, with the exception of a daily crossword puzzle, or two. Bob was an aficionado of crossword puzzles, but he was happy to drop that mental exercise and give you his full attention when you walked in. I helped him to navigate the various university IT systems that are now foisted on us old-timers, with some success. But he was way ahead of me in

Raymond D. Sauer

sauerr@clemson.edu

1 Clemson University, Clemson, SC, USA 
one regard. In the age of email, I marveled at his empty inbox and vowed to achieve some semblance of that myself. He didn't let small things clutter his mind.

Bob was the favorite professor of many Clemson students, including two of my kids. There was always a waiting list to get into his undergraduate course in Public Choice, and he mentored students seeking to do research on sports or public choice. Several of these papers were published in an edition of this journal stemming from the Festschrift we held for Bob on the occasion of his 65th birthday (Shughart 2010). He advised scores of graduate students on their theses and dissertations: his final Ph.D. student received his doctorate last May, only months before his passing. He was a regular at the weekly departmental seminar and Public Economics workshops, occupying the same seat each time. He often had more knowledge of key facts surrounding an issue than the presenters themselves, and let everyone as well as the speaker in on that fact in his unpretentious manner. Bob was (singularly) the department's social committee, seemingly in perpetuity. $\mathrm{He}$ and his wife Anna were our go-to hosts when Nobel Laureates and other dignitaries came to town; they always carried the occasion off with grace and class. They say that time flies when you are having fun, and we had loads of fun indeed. Sirrine Hall, the department's campus home, is not the same without him.

\section{Tollison and sportometrics}

Tollison was the father of sportometrics. Before he arrived on the scene, several talented economists had analyzed what some refer to as "the peculiar economics of sports." But Tollison had something else in mind. He defined sportometrics as "the application of economic theories to the behavior of athletes to explain what they do and to see if what they do can help to explain the behavior of people in other professions and settings. Instead of being about the 'economics of sports,' sportometrics introduces the idea of 'sports as economics"” (Tollison 2008). Together with Brian Goff (Goff and Tollison 1990), Bob edited and co-authored a series of papers that launched the genre. Bob engaged in the economics of sports as well, of course. But everything was economics to Bob. As a keen observer of sports, he could not help but apply economics to the behavior of people engaged in the game.

Bob laid the foundation for this enterprise two or three decades before others understood that sports provided a unique data-rich, lab-like setting that informed economics just as much as economics helped us understand various aspects of sports. Thanks in no small part to Tollison, sportometrics is now part of scholarly activity at the world's best centers of economic inquiry. An excellent recent book, Palacios-Huerta's (2016) Beautiful Game Theory: How Soccer Can Help Economics, is an example of Tollison's vision of sportometrics at its best.

\subsection{Bob Tollison's papers on sports and economics: some highlights}

Bob was a sportsman as well as an economist, and it was quintessentially natural for him to combine the two passions. He played basketball for Wofford College, and later with friends and colleagues. He was a big fan, particularly of the Clemson Tigers, and followed the games closely. But he was a sharp critic of the National Collegiate Athletic Association (NCAA), and was involved as an economic expert witness for three decades in litigation that challenged a number of the monopolistic practices of the college sports 
cartel (Tollison 2012). Much work remains to be done on this front, but the victories of college athletes in the courtroom are due in part to Bob's work on their behalf.

Of course, it was Bob's scholarship on the economics of sports that put him in position to attack the NCAA. He had a knack for being early on the scene of emerging fields in economics and he thus helped define them. Fleisher et al. (1988) examined NCAA enforcement practices through the lens of cartel theory. His 1992 book with Fleisher and Goff catalogued a variety of NCAA policies that had more to do with suppressing economic competition than enhancing competition on the field itself.

Earlier, he and Goff edited and contributed to Sportometrics (Goff and Tollison 1990), a book that accurately captures Bob's approach to sports economics, indeed economics in general. Since then scores of sportometrics papers have been written, some published in the most prestigious economics journals. But Bob was there first, and often.

He was not afraid to tackle controversial issues - the military draft as a public choice problem (Tollison 1970) being an early example. The path from racial segregation to integration in sports (Goff et al. 2002, hereafter GMT) is an example from Bob's work on sports. GMT contrast two economic approaches to the process of racial integration. One focuses on external incentives in the market, the other on managerial alertness and capability. During the period of segregation —as is blindingly obvious today-baseball and basketball teams refused to hire large numbers of black players who were capable of raising the quality of their playing squads. Beginning in the 1950s in Major League Baseball (MLB) and in the 1960s in Atlantic Coast Conference (ACC) basketball, teams began to incrementally add black players to their rosters. GMT ask the question: which force appears to play a more significant role? The external incentive, which would be largest for losing teams, seemingly giving them the most to gain? Alternatively, managerial alertness to the opportunity, which should be correlated with more successful teams. In both MLB and ACC basketball, GMT find that the managerial alertness hypothesis better fits the path of racial integration in sports. Hanssen and Meehan (2008) and Coyne et al. (2010) question the empirical findings in the case of baseball, yet the fundamental issue remains. As GMT put it, the external incentive hypothesis begs the question of why the losing teams "were not doing well in the segregated state of competition" in the first place. Bob was especially good at identifying the issue at the heart of a problem.

I expect that Bob holds a record of some sort for the most papers published on some economic aspect of basketball. From "Arbitrage in a Basketball Economy" to "Homo Basketballus," his insight and wit, and that of his co-authors, were put to use to help us understand both economics and the game of basketball (Grier and Tollison 1990; Goff et al. 1990; McCormick and Tollison 1986). Tollison's 1984 paper with McCormick, "Crime on the Court", arguably had the greatest impact. When the ACC added a third referee to conference basketball games in 1978, the experiment offered an opportunity to explore Gary Becker's model of the economics of crime and punishment, using fouls called on basketball players. The added referee increased the probability that a foul would be detected. Hence, if actual fouls were unchanged, the number of fouls *called* in a game would rise. But player behavior is likely to adapt to the larger probability of being called for a foul, and the number of actual fouls would decline as a result. McCormick and Tollison (1984) found that the number of foul calls fell by more than $30 \%$ with the addition of the third referee, suggesting that this policy innovation resulted in a cleaner game. The NBA followed suit in 1988, after consulting with Tollison, by adding a third referee to its games. Newspaper reports as I write indicate that the league is considering the addition of a fourth referee, pending trials in their developmental league. 
This just scratches the surface of his work in a field of study he helped to create. He did so, in part, by "studying that good ole way," and in the process showing others the way. It will be a long time before we find another one like him.

\section{References}

Coyne, C. J., Isaacs, J. P., \& Schwartz, J. T. (2010). Comment on Hanssen and Meehan, “Who integrated Major League Baseball faster winning teams or losing teams?'. Journal of Sports Economics, 11, 227-231.

Fleisher, A. A., III, Goff, B. L., Shughart, W. F., II, \& Tollison, R. D. (1988). Crime or punishment? Enforcement of the NCAA cartel. Journal of Economic Behavior \& Organization, 10, 153-171.

Fleisher, A. A., III, Goff, B. L., \& Tollison, R. D. (1992). The National Collegiate Athletic Association: a study in cartel behavior. College Station: Texas A\&M University Press.

Goff, B. L., McCormick, R. E., \& Tollison, R. D. (2002). Racial integration as an innovation: Empirical evidence from sports leagues. American Economic Review, 92, 16-26.

Goff, B. L., Shughart, W. F., II, \& Tollison, R. D. (1990). Homo basketballus. In B. Goff \& R. D. Tollison (Eds.), Sportometrics (pp. 121-131). College Station: Texas A\&M University Press.

Goff, B. L., \& Tollison, R. D. (1990). Sports as economics. In B. Goff \& R. D. Tollison (Eds.), Sportometrics (pp. 3-11). College Station: Texas A\&M University Press.

Grier, K. B., \& Tollison, R. D. (1990). Arbitrage in a basketball economy. Kyklos, 43, 611-624.

Hanssen, F. A., \& Meehan, J. W., Jr. (2008). Who integrated major league baseball faster winning teams or losing teams? Journal of Sports Economics, 10, 141-154.

McCormick, R. E., \& Tollison, R. D. (1984). Crime on the court. Journal of Political Economy, 92, 223-235.

McCormick, R. E., \& Tollison, R. D. (1986). Crime and income distribution in a basketball economy. International Review of Law and Economics, 6, 115-124.

Palacios-Huerta, I. (2016). Beautiful game theory: How soccer can help economics. Princeton: Princeton University Press.

Sauer, R. D. (1988). Estimates of the returns to quality and coauthorship in economic academia. Journal of Political Economy, 96, 655-896.

Shughart, W. F., II. (2010). Robert D. Tollison, 65 years on. Public Choice, 142, 261-264.

Tollison, R. D. (1970). Political economy of the military draft. Public Choice, 9, 67-78.

Tollison, R. D. (2008). Sportometrics. In D. Henderson (Ed.), The concise encyclopedia of economics (pp. 471-473). Indianapolis: Liberty Fund.

Tollison, R. D. (2012). To be or not to be? The NCAA as a cartel. In L. Kahane \& S. Shmanske (Eds.), Oxford handbook of sports economics. The economics of sports (Vol. 1, pp. 339-348). Oxford: Oxford University Press. 